\title{
The imperial nexus: the Second World War and the Axis in global perspective*
}

\author{
Daniel Hedinger \\ Historisches Seminar der LMU, Abteilung Neueste Geschichte und Zeitgeschichte, \\ Geschwister-Scholl-Platz 1, 80539 München, Germany \\ E-mail: hedinger.daniel@googlemail.com
}

\begin{abstract}
To date, the alliance between Tokyo, Berlin, and Rome has been interpreted primarily as an alliance between nation-states and has therefore been studied using bi-national approaches. However, this article argues that the strength and globality of the Axis becomes comprehensible if we understand it first and foremost as an alliance between empires. By discussing the interwar years from the viewpoint of trans-imperial cooperation and competition, we discover an imperial nexus. The history, characteristics, diversity, and consequences of this imperial nexus are shown in three parts. The first describes how the nexus helped to bring the distantly located partners together. This occurred against the backdrop of what they called proletarian imperialism, which turned out to be a kind of post-colonial imperialism. The second part analyses how the imperial nexus led others, such as Great Britain, to believe in the existence and strength of a global Axis. In this context, the anti-colonial tendencies put forth mostly by the Japanese turned out to be dangerous. The last part shows how and why the imperial Axis remained intact during the war. Considered from the standpoint of an imperial nexus, the familiar reading of the alliance as well as of the world war shifts. First, Japan and Italy play more important roles than often assumed, while the primacy of Germany is relativized. Second, the chronologies change in relation to the genesis of the Axis and thus the origins of the Second World War. These origins are more strongly associated with non-European world regions and 'colonial peripheries', particularly with China and Ethiopia. Third, the issue of ideological similarities and thus of fascism once again becomes a key focus. Fourth and finally, the Axis appears far more diverse and also stronger than previously understood.
\end{abstract}

Keywords Axis powers, fascism, Germany, imperialism, Italy, Japan, Second World War

\footnotetext{
* My research for this article was generously supported by the Center for Advanced Studies, LMU Munich. For reading, commenting on, and correcting earlier versions of this article, I would like to thank the participants of the 'Axis empires' workshop, as well as Nadin Heé, Mathias Räther, Dona Geyer, Moritz von Brescius and the editors and anonymous reviewers of the Journal of Global History.
} 
The Axis was a global alliance, and as such it was supposed to be part of a global history of the twentieth century. But after the Second World War ended, historiography never saw it that way. A characteristic of the literature about the German-Japanese-Italian relationship during the 1930s and early 1940s is its consistently negative assessment of the quality of this alliance. What we have been presented with over the years is a history full of failures, animosities, and treason. What we have forgotten is that it was the combination, collusion, and coordination of the three powers that shattered the world and brought down its existing order. What we are thereby left with is a history of the Second World War in which the world has been left out.

Scholarship has approached the Axis by means of bi-national analyses, mainly by examining the history of German-Italian or German-Japanese relationships, whereas the Japanese-Italian connection has hardly been studied. ${ }^{1}$ To date, not one monograph has been published that discusses the alliance from the perspective of all three powers involved. But the Axis was a trilateral liaison, and it was this 'trinity' from which the alliance derived its strength as well as its global scope. Furthermore, the bi-national approaches to the history of the Axis cause a second bias: the alliance between Tokyo, Berlin, and Rome has primarily been interpreted as an alliance between nation-states. In contrast, this article will argue that the strength and globality of the Axis becomes comprehensible if we understand it first and foremost as an alliance between empires.

By discussing the interwar years from the viewpoint of trans-imperial cooperation and competition, we discover an imperial nexus, which conjoined and strengthened the Axis. This nexus is evident in an episode that took place on 18 August 1935 in Germany: that evening, the autobahn seemed 'majestic', if also deserted, to the elite of the Third Reich who found themselves on a 'drive through the night'. ${ }^{2}$ Following two days full of meetings and an inspection in Nuremberg and Munich, they were indeed exhausted but happy. Everything at home was in order. Enamoured with visions of grandeur, they were now ready to direct their attention outwards, where it was becoming apparent that a very promising future was awaiting Germany: during the course of the day, they had received word that the negotiations in Paris between Italy, France, and Great Britain on solving the Italian-Abyssinian conflict had been abruptly ended with no results. Hitler's reaction to this was to deliver one of his

1 There are a few exceptions regarding the Japanese-Italian relationship: most recently, Reto Hofmann, The fascist effect: Japan and Italy, 1915-1952, Ithaca, NY: Cornell University Press, 2015; Valdo Ferretti, Il Giappone e la politica estera italiana, 1935-41, Milan: Giuffrè, 1983; Paul Frey, Faschistische Fernostpolitik: Italien, China und die Entstehung des weltpolitischen Dreieckes Rom-Berlin-Tokio, Frankfurt am Main: Peter Lang, 1997; Ishida Ken, Nichi-Doku-I sankoku dōmei no kigen: Itaria nihon kara mita sūjiku gaiko (The origins of the Japanese-German-Italian Pact: Axis diplomacy seen from Italy and Japan), Tokyo: Kodansha, 2013. On the German-Japanese relationship, see Theo Sommer, Deutschland und Japan zwischen den Mächten 1935-1940, Tübingen: Mohr, 1962; Gerhard Krebs, Japans Deutschlandpolitik 1935-1941: eine Studie zur Vorgeschichte des Pazifischen Krieges, Hamburg: Mitteilungen der Gesellschaft für Natur- und Völkerkunde Ostasiens, 1984; Gerhard Krebs, ed., Formierung und Fall der Achse Berlin-Tōkyō, Munich: Iudicium, 1994; Akira Kudō and Nobuno Tajima, eds., Nichi-Doku kankeishi, 1890-1945 (2) Sūjiku keisei no tagenteki rikigaku (History of the Japanese-German relationship, 1890-1945. 2: the multi-dimensional dynamics of the creation of the Axis), Tokyo: Tokyo Daigaku Shuppankai, 2008; Christian W. Spang and Rolf-Harald Wippich, eds., Japanese-German relations, 1895-1945: war, diplomacy and public opinion, London and New York: Routledge, 2006; Masaki Miyake, Nichi-Doku-I sangoku dōmei no kenkyū (Studies on the Japanese-German-Italian Alliance), Tokyo: Nanōsha, 1975. With regard to the German-Italian relationship, a tendency has emerged in recent years to re-evaluate this relationship, thereby granting Italy a larger role and more initiative: see Lutz Klinkhammer, Amedeo Osti Guerrazzi, and Thomas Schlemmer, eds., Die "Achse” im Krieg: Politik, Ideologie und Kriegsführung 1939-1945, Munich: Schöningh, 2010.

2 Diary of Joseph Goebbels, 19 August 1935, http://db.saur.de (consulted 22 March 2017). 
monologues, in which he presented an 'outline of his foreign-policy plans', described by Joseph Goebbels in his diary:

Now the war in Abyssinia will become unavoidable. The Führer is very pleased. ... Colonies to a limited degree. Instead, expansion eastward. The Baltic belongs to us. ... The conflicts Italy-Abyssinia-England, then Japan-Russia are at the doorstep. That is, in a few years perhaps. Then our great historical hour will come. We must be prepared. A grandiose prospect. We are all deeply moved. ${ }^{3}$

For a long time, conventional diplomatic and political history has considered imperialism as a means of opportunistic foreign policy. ${ }^{4}$ But there was always more to it than mere opportunism. In the interwar years, realpolitik was greatly intertwined with ideological considerations. This symbiosis was symbolized by the autobahn over which the Nazi elite travelled that night. It might have served as a job creation project or as infrastructure. However, it meant a great deal more to them. As a symbol of a nation reborn and also of the regime's stake in modernization, it became the ideologically overblown emblem of a fascist revolution. The same can be said about fascist imperialism. As Hitler's monologue shows, the conflict in Africa opened a window of opportunity for him in mid 1935 that directly linked realpolitik with the eastward expansion; the latter, in turn, undoubtedly made up the core of National Socialist ideology. Thus, seen from the imperial nexus of the Axis, a phenomenon manifests itself that can be described as the 'geopolitical-ideological conception of the international system'. ${ }^{5}$ This article argues that the imperial nexus not only brought the Axis powers together but also bound ideology (fascism) to geopolitical aims (imperialism).

By proclaiming the 'Rome-Berlin Axis' around which 'Europe would rotate in the future' on Sunday, 1 November 1936, in the cathedral square in Milan, Mussolini caused much confusion. $^{6}$ The world was puzzled. On the heels of the announcement of the Rome-Berlin Axis came that of the Japanese-German Anti-Comintern Pact at the end of the month. In the context of the escalating Spanish Civil War, it appeared to contemporaries only to be a matter of time before the next world war broke out. ${ }^{7}$ By the time that Italy joined the Anti-Comintern Pact a year later, it was evident that the three powers, which had long been gravitating towards each other, had finally found one another. However, by using the term 'Axis', Mussolini also caused a great deal of long-term confusion. For Europe, the image created may have been quite fitting, since Rome and Berlin lie nearly on the same longitude, and for a few years it did indeed appear as if the two countries forced the rest of Europe to rotate around them. But it proved more difficult to create a term for the inclusion of East Asia. In Europe today, the word 'Axis'

$3 \quad$ Ibid.

4 For instance, Renzo de Felice in Italy and Klaus Hildebrand in Germany. On Hildebrand, see Patrick Bernhard, 'Borrowing from Mussolini: Nazi Germany's colonial aspirations in the shadow of Italian expansionism', Journal of Imperial and Commonwealth History, 41, 4, 2013, p. 634. On de Felice, see Nir Arielli, 'Beyond "Mare Nostrum": ambitions and limitations in Fascist Italy's Middle Eastern policy', Geschichte und Gesellschaft, 37, 3, 2011, pp. 385.

5 Denis Smyth, 'Reflex reaction: Germany and the onset of the Spanish Civil War', in Paul Preston, ed., Revolution and war in Spain, 1931-1939, London: Methuen, 1984, p. 251. See also Glyn Stone, 'The European Great Powers and the Spanish Civil War, 1936-1939', in Robert W. D. Boyce, ed., Paths to war: new essays on the origins of the Second World War, Basingstoke: Macmillan, 1989, p. 202.

6 Benito Mussolini, Opera omnia di Benito Mussolini, vol. 28, Florence: La Fenice, 1959, pp. 69-70.

7 See, for example, the reports from the German embassies and consulates in the political archive of the Foreign Office, Berlin (Auswärtiges Amt - Politisches Archiv, henceforth AA PA), R104883. Concerning international reactions, see also Erich Kordt, Wahn und Wirklichkeit: die Außenpolitik des Dritten Reiches. Versuch einer Darstellung, Stuttgart: Union Deutsche Verlagsgesellschaft, 1948, p. 83. 
still primarily refers to the relations between Berlin and Rome. Outside Europe, however, this narrow view never existed. From the perspective of the United States, references to the Axis automatically included Japan. ${ }^{8}$ Here, I use this idea of a globally allied and operating Axis, which was from its beginning three-dimensional.

In the post-war period, the term 'Axis' may have been used differently, but there was a general tendency to write off the alliance between Japan, Germany, and Italy. The Axis was characterized as a 'spineless alliance', a 'powerless, international grimace', a 'bogus alliance', a 'paper tiger', and a 'hollow alliance'. This negative view of the Axis's quality as an alliance remains intact to the present day. ${ }^{10}$ Recently, the Axis was described as a 'sandcastle'. ${ }^{11}$ In the Definitive encyclopedia and document collection of the Second World War, there is not even an entry for Axis. ${ }^{12}$ Thus, the conventional reading is that the three nations entered into an alliance, which, on a political, military, and economic level, never really existed as such.

On a quite different level, however, the importance of the imperial dimension, and of colonial ambitions, with regard to Germany, Japan, and Italy has been established in recent years through a series of majors works. ${ }^{13}$ At the same time, the neglect of empire in the history of interwar Europe and the origins of the Second World War is increasingly criticized. ${ }^{14}$ In this context, there have been repeated calls for an international or even trans-imperial perspective, but one still does not exist. ${ }^{15}$ However, more recent approaches in new imperial history, transnational history, post-colonial theory, and global history have given us the theoretical and methodological tools to write a history of the imperial nexus of the 1930s and early 1940s.

8 In English, the Anti-Comintern Pact of 1937 was also referred to as the 'Axis pact': see, for example, Kenneth Colegrove, 'The new order in East Asia', Far Eastern Quarterly, 1, 1, 1941, p. 6.

9 Sommer, Deutschland und Japan, pp. 2, 449; Bernd Martin, 'Der Schein des Bündnisses: Deutschland und Japan im Krieg (1940-1945)', in Krebs, Formierung, pp. 27-53; Bill Maltarich, Samurai and supermen: National Socialist views of Japan, Oxford: Lang, 2005, p. 381; Johanna M. Meskill, Hitler and Japan: the hollow alliance, New York: Atherton Press, 1966.

10 Nobuo Tajima, Akira Kudo, and Erich Pauer, eds., Japan and Germany: two latecomers on the world stage, 1890-1945, 3 vols., Folkestone, Kent: Global Oriental, 2009, vol. 1, pp. xiv-xv, vol. 2, p. 196; Ian C. B. Dear and Richard Daniell Foot, The Oxford companion to the Second World War, Oxford: Oxford University Press, 2005.

11 Richard L. DiNardo, 'Axis coalition building', in Thomas W. Zeiler and Daniel M. DuBois, eds., A companion to World War II, Chichester: Wiley-Blackwell, 2013, p. 411.

12 Spencer C. Tucker, ed., World War II: the definitive encyclopedia and document collection, Santa Barbara, CA: ABC-Clio, LLC, 2016.

13 For Japan, see e.g. Louise Young, Japan's total empire: Manchuria and the culture of wartime imperialism, Berkeley, CA: University of California Press, 1998; Prasenjit Duara, Sovereignty and authenticity: Manchukuo and the East Asian modern, Lanham, MD: Rowman \& Littlefield Publishers, 2003. For Italy, see Asfa-Wossen Asserate and Aram Mattioli, eds., Der erste faschistische Vernichtungskrieg: die italienische Aggression gegen Äthiopien 1935-1941, Cologne: SH-Verlag, 2006; Ruth Ben-Ghiat and Mia Fuller, eds., Italian colonialism, Basingstoke: Palgrave Macmillan, 2005. For Germany, see Shelley Baranowski, Nazi empire: German colonialism and imperialism from Bismarck to Hitler, Cambridge: Cambridge University Press, 2011; Mark Mazower, Hitler's empire: Nazi rule in occupied Europe, London: Penguin Books, 2009. Germany is probably the most controversial case, as opinions still diverge somewhat over the question whether the Third Reich really created an empire on European soil. See Birthe Kundrus, 'Colonialism, imperialism, national socialism: how imperial was the Third Reich?', in Geoff Eley and Bradley D. Naranch, eds., German colonialism in a global age, Durham, NC: Duke University Press, 2014, pp. 330-46.

14 See, for example, Susan Pedersen's review of Ian Kershaw, To hell and back, London: Allen Lane, 2015, at https://www.theguardian.com/books/2015/oct/30/to-hell-and-back-ian-kershaw-review (consulted 24 June 2016).

15 See e.g. Ben-Ghiat and Fuller, Italian colonialism, p. 3; Eri Hotta, Pan-Asianism and Japan's war 1931-1945, Basingstoke: Palgrave Macmillan, 2008, p. 107. 


\section{The formation of the Axis and its imperial nexus}

The first imperial impetus came from the Japanese side. In a bold move, the Kwantung Army overran Manchuria in September 1931. Half a year later the Japanese government legalized this move by establishing Manchukuo. For the Japanese, a new empire was born; for the rest of the world, the country was considered to be little more than a Japanese puppet state. But the establishment of Manchukuo marked a turning point in many senses. Shortly afterwards, Japan left the League of Nations. At home, the brave new empire on the continent served to mobilize and radicalize society. At the same time, Manchukuo also brought about a turning point in the history of empires as such, since the regime installed by the Japanese represented the birth of what contemporaries widely viewed as a new form of imperialism. ${ }^{16}$ A contiguous and 'total empire' emerged in which military conquest and domination were combined with industrialization programmes and mass migration projects. ${ }^{17}$ Thus, in many ways, Manchukuo would turn out to be the face of things to come, mainly by showing the potential of bold action and its geopolitical implications. For contemporaries, this was quite obvious. Henry L. Stimson, who had served the United States government for many years, both as Secretary of State and as Secretary of War, wrote that 'the Japanese militarists who planned and executed the Manchurian operations' were probably 'the first active aggressors of World War II': 'There is a direct and significant interconnection between their actions and those others, in Ethiopia, the Rhineland, Spain, China, Austria, Czechoslovakia, and Albania'. 18

However, this interconnection existed from the start in a twofold sense. In Japan, public interest in European fascism skyrocketed in the wake of the 'Manchurian Crisis' ${ }^{19}$ The country experienced an outright fascism boom: 'No topic is more popularly and more heatedly discussed in Japanese periodicals today than is fascism', an article claimed in early $1932 .{ }^{20}$ For many in Japan the 'Manchurian Incident' was a proof of the existence of an authentically Japanese form of fascism, imperialistic from its beginnings. ${ }^{21}$

The dynamics resulting from imperial expansion and domestic revolts that the Japanese empire exhibited in the years 1931-33 impressed Japan's future Axis partners, even though not all reactions were initially positive. ${ }^{22}$ Many people, including Mussolini, first interpreted Japan's Manchurian expansion within the context of fears about a 'yellow peril' and therefore were critical of it. ${ }^{23}$ At the same time, however, such fears and criticism were always voiced with a mixture of fascination. Mussolini, for his part, spoke of 'Japan's imperialistic

16 Leone Penci Mondelli, 'Informazioni, dati e osservazioni sugli avvenimenti di estremo oriente', Gerarchia, 13, 1, 1933, pp. 73-4.

17 See Young, Japan's total empire.

18 Henry L. Stimson, On active service in peace and war, New York: Harper \& Brothers, 1948, p. 220.

19 See Hofmann, Fascist effect, esp. ch. 3, 'The clash of fascisms, 1931-1937'; Daniel Hedinger, 'Universal fascism and its global legacy: Italy's and Japan's entangled history in the early 1930s', Fascism, 2, 2, 2013, pp. 141-60.

20 L. G. Masui, 'The rise of "National Socialism” in Japan', Japan Times \& Mail, 31 January 1932. A copy of the article can be found in Archivio Storico - Ministero degli Affari Esteri, Rome, Affari Politici (henceforth ASMAE, AP), Giappone, Busta 3 (1932), 'Fascismo giapponese'.

21 Imanaka Tsugimaro, 'Fassho no ninshiki to taisaku (Understanding Japanese fascism and countermeasures)', Gaikō Jihō (Diplomatic Review), 63, 662, 1932, pp. 108-17. Or Hōjō Tominosuke, Fassho to kōkoku no shorai (Fascism and the future of the Japanese empire), Tokyo: Kinno Renmei Honbu, 1933.

22 See, for example, ASMAE, AP, Giappone, Busta 3 (1932), 'Fascismo giapponese'. Concerning the 'yellow peril', see also Rudolf Firle, 'Reise-Eindrücke aus Ostasien', Zeitschrift für Geopolitik, 11, 10, 1934, pp. 591-600.

23 Benito Mussolini, Opera omnia di Benito Mussolini, vol. 26, Florence: La Fenice, 1958, pp. 153-6. 
dynamism' with respect, and even with a dose of envy. ${ }^{24}$ As it became evident that the effects of Manchukuo as a 'total empire' were not confined to East Asia, the mutual interest grew and the distances shrank. The events of 1931 in Asia were what first forced the fascist regime in Italy to broaden its horizon and look eastwards. The Duce noted that 'The din of the cannons in Manchuria can be heard with singular immediacy also in Europe. They seem to be strangely close. $^{25}$

In light of the apparent decline of British imperialism, admiration for Japan's aggressive actions and successes resonated in revisionists' minds all over Europe. In this sense, it was the Manchurian project that revealed the similarities and parallelisms of the imperial dreams shared by the future Axis partners. That new ways of dealing with imperial expansion had been opened up was something that the Germans also understood. The Zeitschrift für Geopolitik, for example, argued in 1934 that 'the pan-Asianist idea' had imparted 'a new boost to imperialism under Japan's leadership'. ${ }^{26}$ The world appeared to have turned on its head, and this was certainly not to Germany's disadvantage, as this widely read journal for geopolitics explained:

The Great Powers of Europe (and America) are no longer the masters of decision making in the Far East and thus on the globe; on the contrary, they want to learn from their former pupil Japan in order to prevail in the struggle for their people to survive. ... Already every fourth human today is a member of the yellow race, in a few decades every third earthly inhabitant will be. If this race is then under the strong leadership of Japan, then the powers that think they can create a new worldview in Versailles should watch out that their world is not reduced to an insignificant sideshow when it is decided in the Far East who rules the globe. ${ }^{27}$

In this sense, Japan's establishment of Manchukuo had many lessons to offer: on the one hand, how to survive as a nation by building an empire; on the other, how to deal with other great powers. Thus, from the early 1930s onwards, Japan appeared to many in Germany to be less a guarantor or profiteer of the Versailles order than a nation that had overcome the Washington order. Seen from this point of view, the 'yellow peril' was not Germany's concern, though it was for the other Western powers who still held colonies in Asia. In this context, discourses on the yellow peril started to be suppressed by the censors and disappeared little by little in the German and Italian press. ${ }^{28}$

Moreover, around 1933 Germany, at least, was primarily preoccupied with itself. ${ }^{29}$ Measured against all international standards, the new power holders in Berlin were terribly provincial when it came to global geopolitical contexts. Comments on developments in the Far East were therefore few and far between during this period. But Adolf Hitler did comment

24 Ibid., p. 154.

25 Ibid., p. 155.

26 Hansjulius Schepers, 'Japan und Panasien', Zeitschrift für Geopolitik, 11, 9, 1934, p. 556.

27 Hansjulius Schepers, 'Japan und Panasien', Zeitschrift für Geopolitik, 11, 11, 1934, pp. 701-2.

28 By the end of 1934, Japanese experts no longer took the discussions by fascist Italians on the yellow peril too seriously. Matsushima Hajime, 'Itari no gaikō (Italian foreign policy)', Gaikō Jihō, 72, 716, 1934, p. 67.

29 Japanese experts described the German side in the Manchurian crisis as simply 'not interested' (see Matsunami Niichirō, 'Manshū en shōnin no ryōkankyō (Good conditions for the recognition of Manchukuo)', Gaikō Jihō, 64, 668, 1932, p. 308). See the account of Heinrich Schnee, who was the German member of the Lytton Commission: Heinrich Schnee, Völker und Mächte im Fernen Osten: Eindrücke von der Reise mit der Mandschurei-Kommission, Berlin: Deutsche Buch-Gemeinschaft, 1933, pp. 5-8. 
at least once sympathetically, even favourably, on Japan's actions in Manchuria, in an interview with the Japanese newspaper Asahi in January $1932 .{ }^{30}$ Shortly before the Nazi seizure of power, Japanese experts thus thought that Hitler tended to lean towards the side of Japan, at least on the Manchuria issue. ${ }^{31}$ They were not wrong. Many years before, in his book Mein Kampf, Hitler's racially determined reservations concerning Asians had been overlaid with admiration for Japanese militarism, which had succeeded in defeating Russia in 1904-5. ${ }^{32}$ Now, as a result of the annexation of Manchuria, Japan was even better equipped to stab the Soviet Union in the back, a fact that entailed quite promising options for the future with regard to the geopolitical pursuits of the German dictator. For their part, the Italians were primarily interested in weakening the British empire. But the result was the same: as with the Germans, geopolitical considerations prompted them to follow Japan's imperial experiment with great interest. The future allies were particularly impressed by Japan's industrialization programmes, and by its policy of economic self-sufficiency, as implemented in Manchuria. ${ }^{33}$ As a German book about the country's relationship to Japan in 1936 stated: 'The danger of starvation that brought down a Germany undefeated on the battlefield [in the First World War] no longer threatens Japan today. 34

Against this background, contemporaries in Italy and Germany frequently emphasized the kinship between the Axis empires on an ideological level. For example, on the eve of the war in Europe, the party magazine of Italian fascism, Gerarchia, noted: 'Japanese imperialism ... has a mystical, belligerent and proletarian character, which is in many respects only comparable with the unique proletarian imperialism of Mussolini's Italy that is itself one of the most original historical phenomena of the twentieth century. ${ }^{35}$ Indeed, the idea of proletarian imperialism was rooted in the idea of a 'proletarian nation'. In Italy, the least of the Great Powers, this idea had been circulating as far back as the period before the First World War. Mussolini had seized on it in his speech at the founding of the first fascio in the spring of 1919. ${ }^{36}$ However, by then this idea was not as original as was later proclaimed: it came up at the same time in Japan as well. ${ }^{37}$

In light of all this, many in Japan, Italy, and Germany subsequently believed that it was necessary to have recourse to imperial expansion in order to save their proletarian nation. Thus, the 'belligerent and proletarian imperialism' praised by Gerarchia does indeed appear to

30 Adolf Hitler, interview with Asahi Shimbun, 3 January 1932, http://db.saur.de (consulted 22 March 2017).

31 Matsunami, 'Manshū en shōnin no ryōkankyō', p. 308.

32 Mein Kampf was translated into Japanese at this time: see Adolf Hitler, Yo no tōsō: doitsu kokumin shakai shugi undo (My struggle: the national socialist movement in Germany), Tokyo: Naigaisha, 1932. The critical passages about Japanese and East Asian cultural productivity were usually simply not translated. For the translation process of Mein Kampf, see Iwamura Masashi, “Waga tōsō”: nihongoban no kenkyū (Studies on the Japanese edition of Mein Kampf)', Mediashi kenkyū (Media Studies), 16, 2004, pp. 53-73.

33 For Italy, see, for example, ASMAE, AP, Manciukuò, Busta 1 (1934-39), and Busta 2 (1938-45); Penci Mondelli, 'Informazioni, dati e osservazioni', esp. p. 73. For the German context, see Lily Abegg, Yamato: der Sendungsglaube des japanischen Volkes, Frankfurt am Main: Societäts-Verlag, 1936, e.g. pp. $264-5$ (in a book that was generally quite critical about Japan). On settler colonialism, see Manfred Sell, 'Grundlagen der japanischen Ausdehnungspolitik', Marine-Rundschau, 37, 1932, p. 254. On Japan's new, pan-Asiatic imperialism, see for example, Schepers, 'Japan und Panasien'. For later years, see for example Albrecht von Urach, 'Die Neuordnungsprobleme Japans und Deutschlands', in Walter Donat, ed., Das Reich und Japan: gesammelte Beiträge, Berlin: Junker und Dünnhaupt, 1943, p. 198.

34 Eduard von Pustau, Japan und Deutschland: die beiden Welträtsel, politische, wirtschaftliche und kulturelle Entwicklung, Berlin: Deutscher Verlag für Politik und Wirtschaft GmbH, 1936, p. 144.

35 Curzio Villa, 'Le ragioni del Giappone', Gerarchia, 18, 3, 1938, p. 190.

36 Benito Mussolini, Opera omnia di Benito Mussolini, vol. 12, Florence: La Fenice, 1953, p. 322-3.

37 Konoe Fumimaro, 'Eibei hon'i no heiwa o hai su (A call to reject the Anglo-American-centred peace)', Nibon oyobi nihonjin, 746, 1918, pp. 23-6. 
have been a distinctive and genuine contribution made by the Axis empires; it was an attempt to elevate class struggle to an international level, and thus to overcome class differences and tensions at home. The concept of proletarian empire was highly ambivalent and conflict-laden but it also provided ways to smooth over some contradictory tendencies in the concepts of fascism, imperialism, nationalism, and capitalism. Thus, in mid 1933, many Japanese communists renounced Marxist internationalism and became, in an ironic twist, national socialists. In their 'Apostasy declaration' (tenkō seimeibun) they claimed: 'Also, under today's international conditions, if Japanese were to fight the United States, that war could turn from both countries' war of imperialism into Japan's war of national liberation. Furthermore, a world war fought in the Pacific could turn into a war of liberation for the proletariats of underdeveloped Asian nations from the oppression of Western capitalism. 38

Thus, ideas of a more benevolent imperialism that would enable national liberation and self-determination not only for Japan but for all of Asia, combined with pan-Asianist ideas and new kinds of imperial projects, emerged, which were as ambivalent as they were contradictory. This makes them hard to describe: scholarship on Manchukuo has referred to an 'imperialism after imperialism' or an 'imperialism of free nations'. ${ }^{39}$ However, seen from the perspective of dreams shared by the three Axis powers, I suggest that it would be more fitting to speak of 'post-colonial imperialism'. This emphasizes that the key element in all three dictatorships was not to acquire conventional overseas, economic-based, and distant colonies, but rather to establish contiguous territorial and autarkic empires. One common characteristic in all three countries was a general rejection of the colonialism associated with the so-called 'Age of empire' (1875-1914). For its part, Japan propagandized a benevolent, pan-Asian imperialism that would create free nations in place of suppressed colonized peoples, even though this had little to do with realities on the ground.

When I use the term 'post-colonial' here, I underscore a connotation far less positive than that associated today with 'post-colonial studies', because the post-colonial order which the Axis powers strove to establish was always coupled with the desire to revive imperial rule. Their efforts were directed against other empires, primarily the British, and were not in favour of those being repressed. In the world of nascent decolonization and genuine anti-colonial movements, such ideas were surely anachronistic. But for many in the 1930s they looked new, suitable for carrying imperialism over into a post-colonial world. Even if imperialism proved to be difficult to reinvent in the interwar period, the future Axis powers believed that this was what they were doing.

Italian fascism delighted in underlining the non-colonial character of its quasi-timeless imperio by distinguishing it explicitly from Anglo-Saxon imperialismo. ${ }^{40}$ The latter was criticized for being capitalistic, while the Italian imperio represented its non-materialistic, idealistic antipode. Furthermore, 'for Mussolini fascist imperialism was the ultimate form of

38 Quoted in Hotta, Pan-Asianism, p. 147.

39 Prasenjit Duara, 'The imperialism of "free nations": Japan, Manchukuo, and the history of the present', in Ann Laura Stoler, Carole McGranahan, and Peter C. Perdue, eds., Imperial Formations, Santa Fe, NM: School for Advanced Research Press, 2007, pp. 211-39. For 'imperialism after imperialism', see Louise Young, 'Early-twentieth-century Japan in a global context: introduction: Japan's new international history', American Historical Review, 119, 4, 2014, p. 1122. See also Peter Duus, 'Imperialism without colonies: the vision of a Greater East Asia Co-Prosperity Sphere', in Anthony Best, ed., Imperial Japan and the world, 1931-1941, vol. 4, London: Routledge, 2011, pp. 292-308.

40 Bruno Damiani, 'Impero e imperialismo: natura del conflitto ed aspetti analitici dell'imperialismo britannico: l'esempio dell'Estremo Oriente', Gerarchia, 19, 12, 1939, pp. 781-6. 
anticolonialism', because he believed that the Italian people were fighting their own war against the 'plutocratic empires'. ${ }^{41}$ This was a 'war of the poor, the disinherited, and the war of the proletarians', he wrote; at the same time, it was the ultimate test for the nation, because 'peoples who rise or rise again are imperialistic; renunciation is characteristic of dying peoples' ${ }^{42}$ Thus, nation and empire were inseparably linked and intermingled. In Mussolini's mind, it was imperial expansion which saved the nation from being colonized by others. Thus, by becoming imperialistic one could overcome the colonial world order. These ideas were not alien to Japan, having circulated there from the early Meiji period (1868-1912).

In Nazi Germany as well, post-capitalist and post-colonial imperialism gained ground during the 1930s. ${ }^{43}$ This tendency becomes visible when we consider the fate of colonial ambitions in Africa and compare it to the Nazi empire in eastern Europe. After the seizure of power, colonial experts and proponents of colonial reallocation had nourished high hopes in the new regime. Among them were such distinguished figures as Franz Ritter von Epp, the leader of the German Colonial Society (later the Reichskolonialbund) and Reichsstatthalter (Reich governor) for Bavaria. Others were members of Hitler's first cabinet, such as Alfred Hugenberg, the leader of the Deutschnationale Volkspartei, or Hjalmar Schacht, President of the Reichsbank and Minister of Economics. But all of them lost out in the long run and were marginalized by the regime, as they were not in a position to realize their dream of reviving the German colonial empire during the Third Reich. ${ }^{44}$ Hitler had summarized his priorities in his remarks of 18 August 1935, when he spoke of 'colonies to a limited degree. Instead expansion eastwards. ${ }^{45}$ To counter proponents of colonial reallocation, some exponents of Nazi ideology emphasized that the colonial era was over, once and for all. Among them was Colin Ross, the most widely read travel writer of national socialism, who predicted a new world order based on empire-building, as was already being implemented by states such as Japan. ${ }^{46}$

Paradoxically, the Nazis turned out to be post-colonial by bringing 'home the realities of colonialism' to Europe itself. ${ }^{47}$ The pan-European empire that they created was something the world had never seen before. The Nazi empire on European soil was, at one and the same time, the most pure and the most brutal expression and implementation of their world view. But, besides all differences, what the three powers shared during the 1930s was the idea of reinventing imperialism and bringing it nearer to home, so that the nation could be reborn and thereby survive a worldwide struggle.

Still, shared dreams and utopias were not enough to bring the three powers together. A second imperial impetus - one more likely to accommodate realpolitik and geopolitical considerations - was necessary in order for this mutual interest to develop into something more. Fascist Italy provided this impetus through its conquest of Ethiopia in 1935-36, and in its proclamation of a new Roman empire. The war may have taken place in Africa but, in the context of what has been said above about post-colonial imperialism, it is important to stress

41 Federico Finchelstein, Transatlantic fascism: ideology violence, and the sacred in Argentina and Italy, 1919-1945, Durham, NC: Duke University Press, 2010, p. 34.

42 Quoted in ibid., p. 34.

43 See Hans Goldenbaum, 'Nationalsozialismus als Antikolonialismus: die deutsche Rundfunkpropaganda für die arabische Welt', Vierteljahreshefte für Zeitgeschichte, 64, 3, 2016, pp. 449-89.

44 For a much more nuanced and detailed discussion, see Karsten Linne, Deutschland jenseits des Äquators? Die NS-Kolonialplanung für Afrika, Berlin: Ch. Links, 2008.

45 Diary of Joseph Goebbels, 19 August 1935, http://db.saur.de (consulted 22 March 2017).

46 Colin Ross, 'Die Neuverteilung der Erde: Grundsätzliches zur Kolonialfrage', Zeitschrift für Geopolitik, 13, 9, 1936, p. 589-90.

47 Mazower, Hitler's empire, p. 591. 
that at the very heart of Fascist ambitions was not the acquisition of distant colonies but the rebirth of the great Roman Mediterranean empire. ${ }^{48}$ At the same time, there came a decisive moment in which the regime broke with the previous colonial politics of liberal Italy. Under Fascism there was now a direct interconnection between violence exerted in the war of conquest and a simultaneous internal radicalization. The elite of the Fascist regime took part in combat operations and the approval of the regime back in Italy would never be greater than it was in the immediate aftermath of victory in Ethiopia. ${ }^{49}$

At first, large sections of the Japanese population sympathized with the Ethiopians. ${ }^{50}$ Pan-Asian intellectuals in particular were fiercely critical of the Italians' conduct. ${ }^{51}$ But after the war started in the autumn of 1935, Japanese-Italian relations began to change fundamentally. Suddenly there was no more talk about an 'alliance of the coloured people'. ${ }^{52}$ Changes first occurred on the diplomatic and political levels. ${ }^{53}$ The media soon followed. What had previously been denounced as Western colonialism was now seen as a successful example of 'anti-Western' (mainly anti-British) imperialism. ${ }^{54}$ Thereafter, as Japan began to enjoy an ever closer relationship with Italy, Fascist empire-building in Africa became a recurrent aspect of Japanese pro-fascist propaganda. In such propaganda, Mussolini was also often presented by the Japanese as being a type of benevolent emperor who symbolized the new approaches to imperialism that the Axis powers propagated (Figure 1).

Just as the Japanese and Italians grew closer, so too did the Germans and Italians. The Germans had welcomed the looming conflict in Ethiopia with great enthusiasm - as the episode in August 1935 described above demonstrates. Hitler used the leeway in his new foreign policy in a way that led to the breakdown of the so-called Stresa Front, which had linked Italy to France and Great Britain since April 1935. The remilitarization of the Rhineland in March 1936 was a direct consequence of this. But the German rapprochement with Italy, against the backdrop of the Abyssinian war, did not occur merely out of political calculation. There was also much genuine admiration on the part of the Germans for Italy's brutal colonial actions in Africa. The prestigious publishing house Beck, for example, translated a book in 1937 that the Italian commander-in-chief, Pietro Badoglio, had written on the war. Germany widely welcomed Badoglio's message that it was a war 'from which great lessons may be drawn for the future art of war, even in cases which do not involve a colonial war'. ${ }^{55}$ The Italians' bloody

48 Gaspare Nocera, 'Aspetti geopolitici dell'imperialismo', Geopolitica, 1941, pp. 413-15.

49 Richard J. B. Bosworth, Mussolini's Italy: life under the dictatorship, 1915-1945, London: Penguin Books, 2006, p. 327.

50 On Italian-Ethiopian relations generally, see Ishida Ken, Fashisuto no sensō: Sekaishiteki bunmyaku de yomu echiopia sensō (The Fascist war: reading the Ethiopian war in the context of world history), Tokyo: Chikura Shobō, 2011; Reto Hofmann, 'Imperial links: the Italian-Ethiopian war and Japanese New Order thinking, 1935-36', Journal of Contemporary History, 50, 2, 2015, pp. 215-33; Oka Toshitaka, 'I-Etiopia funsō to nichii kankei no tenkai (The Italian-Ethiopian conflict and the development of Japanese-Italian relations)', Journal of Law \& Politics, 40, 4, 1989, pp. 841-85.

51 Ministero degli Affari Esteri, ed., I documenti diplomatici italiani, series 7, vol. 16, Rome: Libreria dello stato, 1990, p. 627.

52 Concerning the 'Alliance of the coloured peoples', which never materialized, see J. Calvitt Clarke III, Alliance of the colored peoples: Ethiopia and Japan before World War II, Woodbridge: James Currey, 2011.

53 See, for example, Ministero degli Affari Esteri, ed., I documenti diplomatici italiani, series 8, vol. 2, Rome: Libreria dello stato, 1991, pp. 558-62.

54 Izumi Akira, 'Itaria no shuchō no gōrisei (The rationality of Italy's claims)', Gaikō Jihō, 77, 746, 1936, pp. 133-40. Ashida Hitoshi, 'I-E funsō no jitsubutsu kyōkun (Lessons about the true facts of the ItalianEthiopian conflict)', Gaikō Jihō, 76, 742, 1935, pp. 1-4.

55 Pietro Badoglio, Der abessinische Krieg: mit einem Vorwort von Benito Mussolini, Munich: Beck, 1937, p. 182. 




Figure 1. Front cover of the Japanese journal Fassho, showing Mussolini in Libya, August 1939. Source: photograph by the author from the author's collection.

military conduct was seen by many as a model: 'Military experience and lessons from the first modern war of destruction prosecuted on colonial soil' was the subtitle which the military expert Rudolf von Xylander chose in 1937 for his book on the war in Africa. ${ }^{56}$

In the end, the war in Ethiopia served as catalyst for the diplomatic and political convergence of the three powers. From this perspective, they came together around Italy's empire-building. This quickly developed into a trilateral affair. On the eve of the outbreak of the war in Europe, one book, entitled The Pacific age: the problems of the Far East and Italian contributions to solving them, maintained that 'the African war also laid out the general outline of Italian foreign policy', arguing that the Anti-Comintern Pact and the Rome-Berlin Axis were the immediate result of it. ${ }^{57}$ In this sense, the geopolitical background of the Axis alliance, a product of the mid 1930s, was indeed first and foremost an imperial one, and the

56 Rudolf von Xylander, Die Eroberung Abessiniens 1935/36: militärische Erfahrungen und Lehren aus dem ersten neuzeitlichen Vernichtungskrieg auf kolonialem Boden, Berlin: Mittler, 1937.

57 Michele Catalano, L'era del pacifico: $i$ problemi dell'Estremo Oriente: contributo dell'Italia alla loro soluzione, Milan: Fratelli Bocca, 1939. 
first phase of this convergence ended with the Anti-Comintern Pacts of 1936-37 and with each ally's reorganization of its empire.

Thus, what emerged in the late 1930s was an imperial Axis. As this Axis developed, the processes of learning and adopting from one another became more and more frequent. The rhetoric of the three countries' leaders began to sound very similar. By this point, the intellectual currents of Italian fascism, German geopolitics, and Japanese pan-Asianism were heavily referencing each other, if not often coalescing. The imperial nexus also gave meaning to the alliance on an ideological level, and thereby facilitated efforts to identify common enemies, which was a decisive mechanism for the dynamics of a fascist regime. The idea of proletarian imperialism helped them redefine their fight for a new world order as a shared one. In hindsight, the anti-capitalist, non-colonial, proletarian imperialism of the Axis powers may seem absurd. However, the utopia of proletarian and post-colonial imperialism proved to be a powerful one.

\section{The imperial Axis seen from outside}

The full consequences of a looming alliance between Japan, Germany, and Italy became apparent during the 1930s, often first from a third-party perspective. ${ }^{58}$ That the Axis was, above all, a product of dreams of imperial expansion is something that its opponents recognized early on, first and foremost the British:

The chief danger which Imperial Defence has to face at the moment is that we are in the position of having threats at both ends of the Empire from strong military Powers, i.e., Germany and Japan, while in the centre we have lost our traditional security in the Mediterranean owing to the rise of an aggressive spirit in Italy accompanied by an increase in her military strength. ${ }^{59}$

These were the words chosen by the Committee of Imperial Defence at the start of 1937 to describe the situation facing the largest empire of its time. The British cabinet used the reports of the Committee to determine defence policy, and these reports had become increasingly alarming in recent years. In late 1933, the Committee explicitly warned for the first time about a possible alliance between Germany and Japan. ${ }^{60}$ Only the year before, the so-called Ten Year Rule had been discarded. According to this rule, the armed forces could assume that the British Empire would not be involved in a 'Great War' in the next ten years. The rule had been introduced immediately following the First World War on the initiative of Winston Churchill and was reviewed and revalidated annually until its cancellation in 1932 in light of the 'Manchurian Incident', the Great Depression, and the rise of the NSDAP in Germany.

Fears regarding potential cooperation between Japan, Italy, and Germany had already existed for some time, and not only in Britain. In April 1919, negotiations at the Paris Peace Conference stalled after the Italian delegation abruptly departed because they felt that their territorial demands were not being fulfilled, and the Japanese threatened

58 See, for example, Robert Craigie, Behind the Japanese mask: a British ambassador in Japan, 1937-1942, London: Kegan Paul, 2004, pp. 16, 37, and 85.

59 Documents on British foreign policy, 1919-1939 (henceforth DBFP), series 2, vol. 18, London: HMSO, 1980 , p. 969.

60 DBFP, series 2, vol. 20, London: HMSO, 1984, pp. 72-82. 
to follow suit. At the same time, it was unclear how vanquished Germany would behave. In this situation, the US President, Woodrow Wilson, believed that a departure by the Japanese would not only cause the conference to fail but would also destroy his plans for a League of Nations. ${ }^{61}$ Wilson was greatly worried about the situation; it was said that he slept very poorly for days during the height of the crisis. ${ }^{62}$ His British and French colleagues were also alarmed. ${ }^{63}$ However, at this time, the three countries were not yet even thinking about acting in any coordinated fashion. Thus, the constellation that would later be known as the Axis was initially a phantasm beginning to take shape in the minds of their future enemies.

Against this backdrop, the spectre of possible cooperation among the future Axis powers struck terror in the hearts of many during the years that followed. It particularly haunted the British imperial authorities. Geopolitically, the Abyssinian War (1935-1936) posed huge problems for the empire. It was also the reason why, ultimately, it did not prove possible to maintain sanctions against Italy, a decision that was sharply criticized by many, including Winston Churchill, who wrote in retrospect: 'Actually it played a part in leading to an infinitely more terrible war. Mussolini's bluff succeeded, and an important spectator drew far-reaching conclusions from the fact. ... He [Hitler] now formed a view of Great Britain's degeneracy which was only to be changed too late for peace and too late for him. In Japan, also, there were pensive spectators. ${ }^{64}$

The British were not the only ones concerned about a possible imperial nexus between Italy, Germany, and Japan. In light of the 'Italian-Ethiopian conflict', for example, the Soviet government expected an intensification of 'Japanese activities in the Far East' ${ }^{65}$ It was this region of the world in particular that caused also many Americans much concern. ${ }^{66}$ In 1937, the year the Second World War began for East Asia, the historian and journalist William Henry Chamberlin wrote: 'It becomes increasingly clear in retrospect that the seizure of Manchuria in 1931 was much more than an episode of annexation. ... It was a revolution. ... It was a turning point in Japanese history comparable with Mussolini's march on Rome or Hitler's accession to power. ${ }^{67}$ In this sense, the 'Manchurian Incident' was interpreted as the Japanese equivalent to the fascist turning points in Italy and Germany.

In the second half of the decade, particularly after Japan and Germany had signed the Anti-Comintern Pact in November 1936 and Mussolini had proclaimed the Rome-Berlin Axis, the imperial nexus had become all too real for many observers abroad. In fact, in the Anti-Comintern Pact, Germany and Japan committed themselves to little more than the exchange of information as a 'mutual defence against Communist subversion' ${ }^{68}$ The wording of the treaty remained the same when Italy joined a year later. Thus, the purpose of the Anti-Comintern Pact has largely remained a puzzle to researchers. Why should the three powers form an alliance in order to combat the danger of a communist revolution within their

61 Ray Stannard Baker, Woodrow Wilson and world settlement: written from his unpublished and personal material, vol. 1, London and New York: Heinemann, 1923, p. xxxiv; Arthur S. Link et al., eds., The papers of Woodrow Wilson, vol. 58: April 23-May 9 1919, Princeton, NJ: Princeton University Press, 1988, pp. $112,143$.

62 Baker, Woodrow Wilson, vol. 2, p. 223; Link et al., Papers of Woodrow Wilson, p. 244.

63 For the British side, see e.g. Maurice P. Hankey, The supreme control at the Paris Peace Conference 1919: a commentary, London: Allen and Unwin, 1963, p. 131.

64 Winston Churchill, The Second World War: volume I: the gathering storm, London: Cassell, 1966, p. 159.

65 Ministero degli Affari Esteri, I documenti diplomatici italiani, series 8, vol. 2, p. 466.

66 Joseph Clark Grew, Ten years in Japan: a contemporary record drawn from the diaries and private and official papers of Joseph C. Grew, United States Ambassador to Japan 1932-1942, London: Hammond, 1944.

67 William Henry Chamberlin, Japan over Asia, Boston, MA: Little, Brown and Company, 1939, p. 359.

68 Akten zur deutschen auswärtigen Politik, series C, vol. 6, Göttingen: Vandenhoeck \& Ruprecht, 1981, pp. 114-15. 
countries, after such dangers had long disappeared? Research has focused on the Pact's content, often even down to its wording. ${ }^{69}$ The long duration of negotiations and the rather unspectacular content that ultimately resulted has supported the interpretation of the Pact as a weak, bogus alliance, one that was no more than 'a symbolic gesture'. ${ }^{70}$

However, for people at the time the actual wording was secondary. An all too literal interpretation appeared inappropriate, if not misleading, because it seemed obvious that the published agreements were camouflaging secret treaties, such as one creating a concrete military alliance. In the 1930s it was clear that the Anti-Comintern Pact was not directed primarily against domestic threats but against external ones, and therefore contained a clearly imperial dimension. ${ }^{71}$ The Chinese, for example, interpreted the treaty as a stepping stone for Japanese expansion on the mainland. ${ }^{72}$ There was much truth in this, since the Japanese government did indeed attempt to force the Chinese into the Anti-Comintern Pact system.

From 1936 to 1939 , the imperial nexus became particularly obvious in two trouble spots: Spain and China. The idea of an equivalence between those two prompted the fascist magazine Critica fascista to call Spain 'Europe's Far East' and the Far East the 'Meditteraneo nipponico'. ${ }^{73}$ Events in southern Europe were watched in Japan, which exhibited strong pro-Nationalist leanings. The internationalization of the Spanish Civil War benefited Japan geopolitically, because it again directed the world's attention more towards Europe and less towards Asia. ${ }^{74}$ Just as the Anti-Comintern Pact was written into the conflict with China, the Japanese also interpreted the civil war against the backdrop of the conflict in East Asia. In this context, there was often talk in Japan about a global civil war, one that would simultaneously be a conflict between fascism and communism and one between 'haves' and 'have nots'. ${ }^{75}$ Here, ideological objectives were conjoined with geopolitical ones. The challenge that Great Britain faced in it all was that the threat by the Axis imperial nexus over the years had always been twofold. As one of their diplomats noted with concern, the idea of 'two blocs, each based on a rival ideology' was at least as unsettling as the political confrontation between 'have' and 'have not' nations. ${ }^{76}$ Based on the Anti-Comintern Pact, the alliance system had the potential to conjoin both threats. In particular, the anti-colonial components of Axis imperialism would pose nearly intractable challenges to the British empire in the years to come. Therefore, what gave the pact global significance, dynamics, and strength was its imperial nexus.

69 Ōhata Tokushirō, 'The Anti-Comintern Pact, 1935-1939', in James William Morley, ed., Deterrent diplomacy: Japan, Germany, and the USSR, 1935-1940. Selected translations from Taiheiyō sensō e no michi: kaisen gaikō shi, New York: Columbia University Press, 1976, pp. 9-111; Sommer, Deutschland und Japan, esp. pp. 17-93.

70 DiNardo, 'Axis coalition building', p. 407.

71 See for example, DBFP, series 2, vol. 17, London: HMSO, 1979, p. 775; William Lawrence Shirer, Berlin diary: the journal of a foreign correspondent 1934-1941, London: Hamish Hamilton 1941, p. 62; Wilfrid Fleisher, Volcanic isle, Garden City, NY: Doubleday, Doran and Company, Inc., 1941, p. 173; Grew, Ten years in Japan, p. 174; William Edward Dodd, Ambassador Dodd's diary 1933-38, New York: Harcourt, Brace and Company, 1941, pp. 365-6.

72 AA PA, R104884, Trautmann to the Foreign Office, 'Politischer Bericht zu chinesischen Reaktionen bezüglich des Antikomintern Pakts', 28 November 1936.

73 Quoted in Frey, Faschistische Fernostpolitik, p. 291.

74 Florentino Rodao, 'Japan and the Axis, 1937-8: recognition of the Franco regime and Manchukuo', Journal of Contemporary History, 44, 3, 2009, p. 433.

75 Okamoto Tsurumatsu, 'Futatsu no sekaiteki ugoki to supein nairan (Two trends and the civil war in Spain)', Chūō kōron (Central Review), 52, 13, 1937, p. 173-4.

76 DBFP, series 2, vol. 17, p. 90. 
At the same time, there were many British voices that displayed a certain measure of understanding for the colonial demands of Japan, Germany, and Italy. ${ }^{77}$ In light of the looming war between Italy and Ethiopia, Robert Vansittart noted in mid 1935: 'Like fools we made it far worse at Versailles. What has happened in regard to Japan; what is happening in regard to Italy, and what is about to happen in regard to Germany, should surely confirm this view to anyone with political antennae. We are grossly overlanded. ${ }^{, 78}$

Three years later, in late 1938, the Munich Conference and the policy of appeasement showed again how closely trouble spots worldwide were linked by an imperial nexus. The Europe-oriented politics of appeasement were supplemented by the possibility of pursuing a policy of colonial appeasement. Thus, appeasement policies in Europe emerged from the existence of the imperial Axis, bringing impossible challenges for the British empire. ${ }^{79}$ In other words, neither Munich nor appeasement can be understood exclusively in a European dimension. The fact that British leaders took a policy of colonial appeasement into consideration also shows how thoroughly accustomed European statesmen were to thinking in terms of colonial and imperial contexts. But, on the brink of the Second World War in Europe, the unscrupulousness with which Western politicians were willing to bargain with the territories and peoples of non-European colonies was now applied to Europe itself, as the fate of Czechoslovakia proved. This was truly the appropriate prelude to a war in which the National Socialists would ultimately 'bring home the realities of colonialism to Europe'. ${ }^{80}$

Once the imperial ambitions of the National Socialists in Europe itself were plain to see in the wake of the occupation of what was left of Czechoslovakia in the spring of 1939, colonial appeasement was no longer an option. From this point on, Britain fell back once and for all on a political strategy that it had pursued with immense success for centuries, which in essence was to prevent the emergence of a hegemonic imperial power in continental Europe. ${ }^{81}$ This was also the reason why the moral frontlines were not yet as distinct when the war in Europe started as they would seem after 1945. In a widely read article with the title 'Not counting niggers', George Orwell wrote in July 1939:

The unspoken clause is always 'not counting niggers'. ... how can we 'fight Fascism' except by bolstering up a far vaster injustice? For of course it is vaster. What we always forget is that the overwhelming bulk of the British proletariat does not live in Britain, but in Asia and Africa. ... What meaning would there be, even if it were successful, in bringing down Hitler's system in order to stabilize something that is far bigger and in its different way just as bad? ${ }^{82}$

Thus, Britain went to war in September 1939, when the imperial Axis seemed weak, and in the belief that its empire would save the nation once again. By winning, the nation would also save its empire again. The first assumption turned out to be correct, but the second was an illusion.

77 One of the more prominent among them was Edward Hallett Carr, The twenty years' crisis, 1919-1939: an introduction to the study of international relations, London: Macmillan, 1939.

78 DBFP, series 2, vol. 14, London: HMSO, 1976, pp. 308-9.

79 Reinhard Meyers, 'British imperial interests and the policy of appeasement', in Wolfgang J. Mommsen and Lothar Kettenacker, eds., The fascist challenge and the policy of appeasement, London: George Allen and Unwin, 1983, pp. 339-51. See also Ashley Jackson, The British empire and the Second World War, London: Hambledon Continuum, 2006, p. 16.

80 Mazower, Hitler's empire, p. 591.

81 Meyers, 'British imperial interests', p. 342.

82 George Orwell, 'Not counting niggers', The Adelphi, July 1939. 
Throughout the 1930s, it was primarily the British empire that felt threatened by the cooperation between the Axis powers. After the war in Europe broke out, the imperial nexus remained intact and subsequently developed into a major challenge for the United States as well. In the spring of 1941, the infamous negotiations between the United States and Japan commenced, which were meant to keep the latter out of the war. These negotiations are readily cited as evidence that Japan attempted to avoid the war up to the last minute. ${ }^{83}$ Yet we should ask ourselves why these negotiations were so ineffective and inconclusive. It seems that the answer is relatively simple and once again directly connected to the Axis's imperial nexus. The Americans presented two fundamental demands: that Japan should pull out of China, and that it should break with the European Axis powers. These two points were directly linked in American eyes.

What was decisive for the failure of the negotiations, however, was that the Japanese side apparently interpreted the situation the same way. Time and again, it is maintained that the American-Japanese negotiations must have shaken the Tripartite Pact to its roots. It is implied that Japan did not want to surrender its conquests in China, but did indeed consider leaving the Tripartite Pact, which was thus but a 'sham front'. ${ }^{84}$ Yet there is no evidence to support the contention that the Japanese rulers ever seriously considered abandoning the alliance established in the autumn of 1940. On the contrary, in the final phase of the negotiations, in November 1941, Foreign Minister Tōgō Shigenori forbade the negotiators in Washington from offering the Americans a pull-out from the Axis. ${ }^{85}$

It was clear to the Japanese that they could not give up the alliance with the European Axis powers if they wanted to pursue their imperialistic aims in East Asia. Following a defeat of Germany in Europe, the Western powers would no longer have made any concessions to Japan's ambitions. In other words, the Japanese could not and did not want to leave their partners in mid 1941. The dismal failure of the negotiations can therefore be read as proof that the imperial nexus of the Axis was real for both sides. This shows that the impact of the alliance cannot be measured solely by the cooperation that actually occurred among its members. Instead, it must be acknowledged that, even before the global war broke out, the alliance highlighted the interdependencies in the field of global imperial competition that developed into a leitmotif for the Axis powers and their future enemies.

Starting in the mid 1930s, the world was shaken by a series of wars in Ethiopia, Spain, and China. The three wars had two things in common: they took place far from the global centres of power but, at the same time, they occurred in regions of increased colonial competition, in places where imperial ambitions collided. The 'extreme violence of the twentieth century' has been explained by 'empires in decline'. ${ }^{86}$ But it was both imperial expansion and the decline of

83 See Iguchi Takeo, Demystifying Pearl Harbor: a new perspective from Japan, Tokyo: International House of Japan, 2010; Eri Hotta, Japan 1941: countdown to infamy, New York: Vintage Books, 2015, e.g. p. 21; Inoue Toshikazu, Senzen nihon no gurōbarizumu: senkyūhyaku sanjūnendai no kyōkun (Japanese globalism in prewar time: a lesson from the 1930s), Tokyo: Shinchosha, 2011, pp. 3-4. Such interpretations have a longer tradition: see Shigenori Tōgō, Japan im Zweiten Weltkrieg: Erinnerungen des japanischen Außenministers 1941-42 und 1945, Bonn: Athenäum-Verlag, 1958; Konoe Fumimaro, Ushinawareshi seiji: Konoe Fumimaro no shuki (Lost politics: the recordings of Konoe Fumimaro), Tokyo: Asahi Shinbunsha, 1946, p. 3.

84 Sommer, Deutschland und Japan, pp. 447-8. See also Mamoru Shigemitsu, Japan and her destiny: my struggle for peace, New York: E. P. Dutton \& Co., 1958, p. 229-30.

85 See also, Hotta, Japan 1941, p. 261.

86 Niall Ferguson, The war of the world: twentieth-century conflict and the descent of the West, London: Penguin Books, 2007, p. xli. 
empires that led to war and violence. In other words, volatility in the imperial sphere turned out to destabilize the order of the world in the interwar years.

The wars of the 1930s and their imperial dimensions and implications were what drew the three Axis powers together. Each side admired the others for their empire, their (often imagined) strengths, and their future potential. Each recognized their own imperial ambitions in those of the others and valued the challenge these posed to the established order, because such a challenge presented possibilities for action in their own border regions. This was particularly true for Germany, whose territorial expansion came comparatively late. The Germans studied and duly acknowledged the head start that Italy and Japan enjoyed. For example, in August 1940, the editors of Zeitschrift für Geopolitik published an article written by an Italian on the 'Fascist system of settlement in Africa', commenting that this concerned issues 'which will become pressing ones, with the impending colonial activities of the Reich'. ${ }^{87}$

\section{The imperial nexus of the Axis during the Second World War}

When the European war started in 1939, the three countries had still not entered into any formal military alliance. For this, a third and final imperial impetus was needed, which this time was provided by Germany. German empire-building might have started late, but it was then implemented at breath-taking speed: one year after the Anschluss of Austria, the Reich already included much of Czechoslovakia. A year later, by the summer of 1940, parts of Poland and large swathes of western and northern Europe had been added. Parts of southeastern and eastern Europe followed. Three years after the signing of the Munich agreement, around half of Europe's peoples lived in what was now Hitler's empire.

It was this third imperial impetus, coming from the German side, which first ensured the survival of the imperial Axis, and then eventually enabled it to become a war alliance. In this sense, the expansion that turned a European and an Asian war into a global one can only be understood in the context of the imperial nexus. After the shocking consequences that the Hitler-Stalin Pact of August 1939 had for Japan, it was the resounding success of the Germans in Poland and then in northern Europe (Denmark and Norway) that temporarily assured the continued survival of the Axis alliance.

Finally, the fall of France in June 1940 changed the geopolitical situation globally once and for all. Spellbound by the implications of the German conquest, the Japanese elite began to think about the colonial inheritance being left behind by the Dutch, the French, and, in what seemed a foreseeable time, the British. This helped outline their expansionist plans in greater detail, because now the door to Southeast Asia stood wide open. Decision-making processes in Japan focused again on strengthening the Axis. ${ }^{88}$ In light of the successes of Germany's Blitzkrieg, both the media and the public at large expressed very enthusiastic pro-German sentiments, which in turn may have enticed hesitant politicians and naval officers to finally support an Axis-friendly policy. ${ }^{89}$ In the end, it was the prospect of acquiring the

87 Paolo D'Agostino Orsini di Camerota, 'Das faschistische Siedlungssystem in Afrika', Zeitschrift für Geopolitik, 17, 8, 1940, p. 362.

88 Gaimushō, eds., Nihon gaikō monjo: nichi-Doku-I sangoku dōmei kankei chōshoshü (Papers on the Alliance between Japan, Germany, and Italy), Tokyo: Gaimushō, 2004, p. 12.

89 Ian Kershaw, Fateful choices: ten decisions that changed the world, 1940-1941, London: Penguin Books, 2008, p. 121. 
colonies of the defeated European countries of France and the Netherlands that motivated Japan to sign the Tripartite Pact with Germany and Italy on 27 September 1940.

Under the spell of Germany's successes in Europe and in parallel with the formation of the Tripartite Pact, the Greater East Asia Co-Prosperity Sphere was proclaimed in late June $1940 .{ }^{90}$ At the same time, exhilarated by German successes, the Japanese prime minister, Konoe Fumimaro, announced the end of the old world order and the beginning of a new one. Japan's new policy was broadly influenced by the Nazis' plans for a new European order, just as, some years earlier, Japan's plans for an East Asian empire had influenced her European partners. ${ }^{91}$ Thus, in mid 1940 the imperial nexus crystallized once again.

If one looks at the Tripartite Pact itself, the imperial dimensions of the Axis project are plain to see. In the regional context, the alliance based on the Tripartite Pact and the Anti-Comintern Pacts described the imperial setting of each region by including smaller partners such as Manchukuo, the Reorganized National Government of the Republic of China, or Spain. After the German onslaught began on the Soviet Union in mid 1941, Romania, Denmark, Finland, Croatia, Slovakia, and Bulgaria soon joined the renewed Anti-Comintern Pact as well. Seen in this light, these pacts were 'nothing less than the international diplomatic expression of Carl Schmitt's Großraum concept'. ${ }^{92}$

For a brief moment during 1942, the Axis empires seemed to be very close to the realization of their New World Order. By then, after ten years of significant and seemingly almost effortless territorial expansion, Germany and Japan had indeed become imperial superpowers. At the height of its expansion, Hitler's empire consisted of land masses larger than the United States, 'more densely populated and more economically productive than anywhere else in the world'. ${ }^{93}$ At the same time, the Nazi empire was producing twice as much steel as the United Kingdom and the Soviet Union put together. ${ }^{94}$ The newly created German empire in eastern Europe may have brought nothing but destruction and annihilation to its inhabitants, but for the Axis powers it looked as if this conquest would eliminate once and for all any shortages of raw materials and labour in Europe.

In terms of its geographical stretch and its population, the Japanese empire surpassed even the German Reich. At the beginning of 1942, the Japanese government quickly took steps to consolidate the newly conquered territories in Southeast Asia by integrating them into the 'Co-Prosperity Sphere'. Japanese rule now extended from Manchuria to Singapore. Wendell Willkie, the defeated Republican presidential candidate of 1940 warned:

Japan's dreams have at last taken on reality to our eyes, for we have seen the Japanese conquer a great part of the empire they planned.... If all this [the fall of China and India] were to come about, we should witness the creation, not merely of a great empire, but of perhaps the biggest empire in history; an empire composed of about a billion people living on approximately fifteen million square miles of land; an empire occupying one

90 For the Greater East Asia Co-Prosperity Sphere, see Kawanishi Kōsuke, Teikoku nihon no kakuchō to hōkai: daitōa kyōeiken eno rekishiteki tenkai (The rise and fall of the Japanese empire: the historical development leading to the Great East Asian Co-Prosperity Sphere), Tokyo: Hosei Daigaku Shuppankyoku, 2012.

91 See, for example, Okamoto Tsurumatsu, 'Sūjikukoku kawa kara mita 'saigo no sekai sensō (The "last world war” as seen from the side of the Axis powers', Gaikō Jihō, 104, 909, 1942, pp. 17-23.

92 Mazower, Hitler's empire, p. 580.

93 Ibid., p. 3.

94 Richard Overy, Why the allies won, New York: Norton \& Co., 1996, p. 4. 
third of the earth and including one half of its total population. ... Moreover, this empire would include within itself almost every resource that can be imagined. ${ }^{95}$

The nightmare scenario Willkie envisioned never materialized but, even after Axis setbacks from mid 1942, the imperial nexus did not simply disappear. Despite all the shortcomings and the annihilating violence, despite so much failure of imperial rule on the part of the Axis, the alliance maintained an imperial visage during the war, even in its final years. One reason for this was that the dream of a new Axis world order played an important role for the designs of a post-war world order, especially for their opponents. It was the successes and the strength of the Axis alliance until mid 1942 that forced its enemies to devise new visions of a global order that would decisively shape the post-war period. ${ }^{96}$

But, the dreams of huge, territorially linked empires were also crucial for the mobilization for total war within the Axis societies. ${ }^{97}$ Eventually, the Axis manifested itself only in the utopias and dreams of an ultimate victory that was receding further and further from the realm of possibility. Yet it was in these dreams that the imperial dimension proved so effective in mobilizing its societies down to the final days of the war. Thus, if we want to understand why the Axis powers continued to fight for three more bloody years after the defeats in the second half of 1942, still able and willing to inflict a greater loss of blood on their enemies then they suffered themselves, this dimension is crucial.

After Pearl Harbor and Japan's entry into the war, trust in the power of the other empires became particularly important. ${ }^{98}$ In particular, the German admiration for Japanese empirebuilding proved to have a long-term effect. When the defeat at Moscow threw the Reich into a serious crisis, it was the rapid-fire victories of its allies that caused euphoria. ${ }^{99}$ Furthermore, the Japanese conquests offered Germans a very promising long-term perspective. German journals and newspapers were now full of reports emphasizing that the Japanese empire had at its disposal 'the largest natural resources existing anywhere in the world' and that it therefore 'would never be able to be defeated'. ${ }^{100}$ Signal, a propaganda photo magazine of the German Wehrmacht, which was distributed all over Europe and which had a total circulation of about 2.5 million at its height, made a point time and again of emphasizing 'the endurance of Japan's defence economy'. ${ }^{101}$ The subtext of these articles was that the German empire would no longer be threatened with the same fate it experienced in the First World War, now that it had such an ally. ${ }^{102}$ Similarly, magazines such as Berlin-Rom-Tokio, closely associated with

95 Wendel L. Willkie, One world, New York: Pocket Books Inc., 1943, pp. 89-90.

96 On post-war Allied planning, see also Mark Mazower, No enchanted palace: the end of empire and the ideological origins of the United Nations, Princeton, NJ: Princeton University Press, 2008.

97 Daniel Hedinger, 'Colonialism and mass dictatorship: the imperial Axis and the home front in Japan, Italy and Germany', in Paul Corner and Jie-Hyun Lim, eds., The Palgrave handbook of mass dictatorship, Basingstoke: Palgrave Macmillan, 2016, pp. 35-49.

98 For the Italian side, see, for example, the documentaries Per la grande Asia Orientale and Nuovo ordine in Asia Orientale, both 1942, online at the Archivio storico luce, http://www.archivioluce.com/archivio (consulted 22 March 2017).

99 On the immediate reaction of the Nazi elites and Hitler, see Max Domarus, Hitler: speeches and proclamations, Wauconda, IL: Bolchazy-Carducci Publishers, 1990, pp. 2346, 2526-7; Kordt, Wahn und Wirklichkeit, pp. 318, 322. Galeazzo Ciano, Diario 1937-1943, Milan: BUR, 1998, p. 564. On the reactions of the German population, see Heinz Boberach, ed., Meldungen aus dem Reich 1938-1945: die geheimen Lageberichte des Sicherheitsdienstes der SS, Herrsching: Pawlak, 1984-85, vol. 9, pp. 3101-2.

100 Signal, 23, December 1943, pp. 8, p. 11.

101 Signal, 9, May 1943, p. 15.

102 Signal, 14, July 1943, pp. 18, 21-3. 
the Foreign Ministry and Joachim von Ribbentrop, stressed also the 'unassailability' of the Japanese empire. $^{103}$

Admiration for Japan's successful empire-building was common in the Nazi elite, as a diary entry from Joseph Goebbels in June 1943 shows: '[Japan] is conducting a total war that is in many respects more total than ours. Here and there we could follow the example of the Japanese and their determination to bring the war to a favourable outcome. ${ }^{, 104}$ The idea that Japan was somewhat ahead of Germany was a topic that Goebbels would return to time and again. On another occasion, he noted about Japanese occupation policy: 'Meanwhile, Japan is seriously undertaking a total war.... The policy that the Japanese pursue in the occupied areas is also downright exemplary. They act with extraordinary cleverness and thereby earn a great deal of sympathy for themselves. ${ }^{105}$

On the one hand, such views show how little leading National Socialists knew about the actual conditions in the Far East. On the other, depictions of race changed in the context of such a self-critical tone. It has been argued repeatedly that Hitler and the National Socialists strove for world domination and therefore would have sooner or later run into conflict with the Japanese, whom they considered to be racially inferior. ${ }^{106}$ But there is very little evidence supporting this reading. On the contrary, during the final years of the war, the National Socialist media openly celebrated the 'loss of Asia for the white race', meaning that the Japanese successes showed that the white race did not belong there. ${ }^{107}$ 'Europe for the Europeans, East Asia for the East Asians' was the motto propagated by magazines such as Berlin-Rom-Tokio. ${ }^{108}$ The way that the Japanese race was depicted thus changed: Signal told its readers in May 1943 that 'The Japanese are a true community of peoples. Although made up of blood lines of very different origins, racially they have formed into a complete union.109 There was a post-colonial reading to all of this. As late as 1944, Albrecht von Urach wrote: 'Today Japan gives the cohesive racial corpus of East Asia the autonomy that they never would have achieved under previous colonial rule. ... Manchukuo is an economic and political masterpiece, no longer viewed as a colonial project, but as a vision, created as a model for a coming Greater People's Empire (Groß-Völker-Reich). ${ }^{110}$

Thus, even amid Germany's downfall, Germans were still hopeful that Japan's effort to establish a new order in East Asia would succeed. The ever-illusory hope of ultimate victory was therefore transferred to the ever more distant ally, and nurtured by Japan's very existence, against all reason.

\section{Conclusion}

In this article, I have argued that we should not think of the Axis merely in terms of how it ended. In the early 1930s, it was initially Japan's expansion into Manchuria that prompted

103 Berlin-Rom-Tokio, 5, 7, 1943, p. 2.

104 Diary of Joseph Goebbels, 5 June 1943, http://db.saur.de (consulted 22 May 2016).

105 Ibid., 1 April 1944.

106 On world conquest, see Gerhard Ludwig Weinberg, Germany, Hitler, and World War II: essays in modern German and world history, New York: Cambridge University Press, 1995, p. 36. On a coming conflict with the Japanese, see Gerhard Ludwig Weinberg, Visions of victory: the hopes of eight World War II leaders, New York: Cambridge University Press, 2005, p. 10.

107 Signal, 9, May 1943, pp. 15, 30.

108 Berlin-Rom-Tokio, 4, 1, 1942, pp. 3-4.

109 Signal, 9, May 1943, p. 30.

110 Berlin-Rom-Tokio, 6, 2, 1944, p. 5. 
mutual interest in fascism and the discovery of common geopolitical goals. In the mid 1930s, Italy's war in Ethiopia prepared the way for a political convergence that served as the imperial background for the subsequent Anti-Comintern Pacts. Thereafter, it was the genesis of a German empire on European soil that laid the foundations for the military alliance. Thus, the three powers appear to have found each other and to have come together within an imperial nexus. The Axis powers may have acted as nation-states, but they did so in an imperial context, in a world largely divided up between competing imperialisms. This was what gave them tremendous political bargaining power and explains why they were feared by their future enemies.

Nor should we judge the Axis solely from the last few years of the war. The road leading to the Second World War was a long and winding one, and the globality of the imperial nexus is central to understanding this. Most histories of the war are focused on the years 1939-45, including the few dedicated to depicting global history. ${ }^{111}$ They have therefore evaluated the quality of the Axis alliance against the backdrop of military, political, and economic cooperation during this period. By focusing on the imperial nexus, this article has shown that there were other dimensions of interaction, exchange, and mutual influence, beyond the conventional bi-national model.

Considered from the standpoint of an imperial nexus, the familiar reading of the Axis and the war shifts. First of all, Japan and Italy play more important roles, while the primacy of Germany is relativized. Second, the chronologies change in relation to the genesis of the Axis and thus the origins of the Second World War. These origins are more strongly associated with non-European world regions and colonial 'peripheries', particularly with China and Ethiopia. Third, the issue of ideological similarities, and thus fascism, once again becomes crucial. Finally, the Axis appears far more diverse, and also stronger, than previously understood.

The imperial nexus of the Axis was quickly forgotten after 1945 in the context of the Cold War and decolonization, when it became necessary to reintegrate (West) Germany, Japan, and Italy as nation-states within the Western bloc. Little room was left for an imperial history of the first half of the twentieth century, for the history of the Axis per se, or for a global comparative history of fascism in general. This lack of interest in the imperial nexus was evident on all sides. First, the former colonized peoples saw the decolonization process primarily in the context of national liberation wars, which made it seem less opportune to emphasize the imperial nexus of the Second World War. Second, the defeated nations eagerly forgot their imperial and colonial past. ${ }^{112}$ Third, the victors faced new circumstances. Winston Churchill, in the summer of 1940, had ended his famous speech on the looming defeat in the fall of France with the widely quoted words: 'if the British Empire and its Commonwealth last for a thousand years, men will still say: "This was their finest hour.",113 But after the war, when it became clear that the British empire would not last a thousand years, the British struggle was nationalized, and the war was Europeanized. ${ }^{114}$ Seen in this light, the imperial dimension of the Axis and thereby

111 See, for example, Gerhard Ludwig Weinberg, A world at arms: a global history of World War II, Cambridge: Cambridge University Press, 1994.

112 For Japan, see Sebastian Conrad, “The colonial ties are liquidated”: modernization theory, post-war Japan and the global Cold War', Past \& Present, 216, 2012, pp. 181-214.

113 Winston Churchill, speech in the House of Commons, 18 June 1940, http://www.winstonchurchill.org/ resources/speeches/1940-the-finest-hour/their-finest-hour (consulted 23 March 2017).

114 See, for example, Winston Churchill, The Second World War: their finest hour, London: Cassell, 1966. 
the Second World War got lost twice within ten years, both in reality and in the minds of the actors who participated in the war.

Daniel Hedinger is associate professor (PD) at LMU Munich. He specializes in trans-national history, with a focus on modern Japanese and European history. Currently, he is working on a book about the Axis alliance and the Second World War in global perspective. 